\title{
Toxicological Effect of Canarium odontophyllum Extract Against Acute Lymphoblastic Leukemia CCL-119 Cell Line
}

\author{
Elda Surhaida Latif ${ }^{1}$, Dayang Fredalina Basri ${ }^{1 *}$, Tava Shelan Nagapan ${ }^{1}$ \\ ${ }^{1}$ School of Diagnostic \& Applied Health Sciences, Faculty of Health Sciences, Universiti Kebangsaan Malaysia, Jalan Raja \\ Muda Abdul Aziz, 50300 Kuala Lumpur, Malaysia
}

Received: December 13, 2017; Accepted: December 29, 2017; Published: January 20, 2018

*Corresponding author: School of Diagnostic \& Applied Health Sciences, Faculty of Health Sciences, Universiti Kebangsaan Malaysia, Jalan Raja Muda Abdul Aziz, 50300 Kuala Lumpur, Malaysia, Tel: +603-9289-7652,E-mail: dayang@ukm.edu.my

\begin{abstract}
Introduction: Acute Lymphoblastic Leukemia (ALL), a common childhood hematological malignancy, is clinically treated with various chemotherapy drugs in the treatment regimen. One of the drugs in the regimen is dexamethasone (DEX), which is associated with treatment toxicity especially at high doses. To reduce the high rates of toxic death in pediatric patients, natural products have been the focus of such studies. Canarium odontophyllum (CO) has been proven to be cytotoxic against various type of solid cancer cells without affecting normal cells. Thus, this study aims to determine the cytotoxicity and genotoxicity of CO acetone extract against CCL-119, a childhood T-ALL malignancy cell line.
\end{abstract}

Methods: The cytotoxicity effect of CO extract and DEX were assessed using MTT assay. Mode of cell death was determined by Annexin V-FITC staining using flow cytometry and DNA integrity was determined using fluorescent alkaline Comet assay. Cell morphology was observed using Giemsa staining.

Results: The $\mathrm{CO} \mathrm{IC}_{25}$ and $\mathrm{IC}_{50}$ were $0.37 \pm 0.02 \mathrm{mg} / \mathrm{ml}$ and $0.93 \pm$ $0.09 \mathrm{mg} / \mathrm{ml}$ respectively, whereas DEX IC ${ }_{25}$ and IC $_{50}$ were $0.15 \pm 0.01$ $\mu \mathrm{g} / \mathrm{ml}$ and $0.32 \pm 0.01 \mu \mathrm{g} / \mathrm{ml}$ respectively. CO extract and DEX induced DNA damage of treated CCL-119 cells while mode of cell death is via apoptosis. Cell morphological study showed blebbing and shrinkage of cells following CO and DEX treatment.

Conclusion: This study showed that $C$. odontophyllum has a promising potential to be developed into ALL treatment which may improve life expectancy of pediatric with leukemia.

Keywords: Acute Lymphoblastic Leukemia; Canarium odontophyllum; Apoptosis; DNA damage

\section{Introduction}

Acute Lymphoblastic Leukemia (ALL) is the most common form of hematological malignancy in pediatric and adolescents. ALL is manifested by the rapid proliferation and abundant accumulation of dysfunctional lymphoid lineage blast cells in the bone marrow and peripheral blood [1]. Approximately 54,000 new cases of childhood ALL has been reported yearly in Asia [2]. ALL is commonly treated with various chemotherapeutic agents which include dexamethasone, methotrexate and doxorubicin in the treatment regimen. However, this regimen causes concerns over treatment toxicity and toxic death especially at high doses
[3]. Natural products especially plant extracts can be used as alternative treatment to treat leukemia. This is because plant extracts are not cytotoxic to normal cells and able to inhibit carcinogenesis [4].

Canarium odontophyllum which is also known as dabai or kembayau is a fruit-bearing tree that can be found vastly in Borneo, Brunei, Sumatra and it belongs to Burseraceae family [5]. This plant is classified as an under-utilized fruit due to lack of promotion and its economic potential has not been fully explored yet. Few studies have been conducted on different parts of this plant, especially extracts from the leaf and twigs which exerts cytotoxicity towards colorectal cancer [6]. The twigs of C. odontophyllum have many phytochemicals which include terpenoid, flavonoid, tannin, saponin and phenolic compound [7]. Terpenoids have been reported to be responsible for the cytotoxic activity in cancer cell lines $[8,9,10]$.

Acetone extract of $C$. odontophyllum twigs is able to induce apoptosis and DNA damage in colorectal cancer HCT 116 cell line [6]. Generally, apoptosis is one of the mode of death that is favourable in cancer research. This is because the apoptotic bodies formed will undergo phagocytosis without inducing inflammation to the body system. In addition, this process does not affect the surrounding neighbouring cells [11]. Moreover, plant extracts are able to inhibit cell proliferation by inducing DNA damage which has the potential to be developed as anticancer agents [12].

Therefore, this study has been conducted to determine the cytotoxicity and genotoxicity of acetone extract of twigs $C$. odontophyllum against acute T-lymphoblastic leukemia cell line from, CCL-119.

\section{Materials and Methods}

\section{Plant Material}

C. odontophyllum twigs were obtained from Sarawak and placed in UKM Herbarium with a voucher number of UKMB 40052. A stock solution of acetone extract C. odontophyllum twigs was prepared by dissolving $200 \mathrm{mg}$ of pounded acetone extracted twigs in $1 \mathrm{ml}$ of $100 \%$ DMSO. The stock solution was mixed using autovortex for five to ten minutes. Then, the mixture 
was centrifuged for five minutes at $2500 \mathrm{rpm}$. The stock solution was then filtered using $0.22 \mu \mathrm{M}$ nitrocellulose membrane filter and kept in $-20{ }^{\circ} \mathrm{C}$ refrigerator.

\section{Preparation of Cell Culture}

CCL-119 acute lymphoblastic leukemia cell line was obtained from American Type Culture Collection Rockville, MD USA. The cell line was maintained in complete growth medium RPMI1640 media (Sigma Aldrich, USA). The medium was enriched with $10 \%$ of Fetal Bovine Serum (FBS) and 1\% of PenicilinStreptomycin. Cells were cultured at $37^{\circ} \mathrm{C}$ in $5 \% \mathrm{CO} 2$ condition at Biocompatibility and Biotechnology Laboratory, Faculty of Health Sciences, Universiti Kebangsaan Malaysia. The cultured cells were observed and checked daily byusing an inversion microscope to see the morphology and cell growth, cultured up to 70-90\% confluence of cells.

\section{Evaluation of Cytotoxicity}

MTT [3-(4,5-dimethyl-2 thiazolyl)-2,5-diphenyl-2Htetrazolium bromide] assay was performed to evaluate cytotoxicity of acetone extract of twigs at concentration ranging from $0.125 \mathrm{mg} / \mathrm{ml}-2 \mathrm{mg} / \mathrm{ml}$ at 72 hours against CCL-119 cells. The cells were counted to achieve a concentration of $1 \times 105$ cells $/ \mathrm{ml}$. A total volume of $150 \mu \mathrm{l}$ of cell suspension was seeded in each well of the 96-microtiter plate. The seeded cells were incubated for 48 hours before they were treated with extract. Dexamethasone was used as a positive control at concentration ranging from $0.5 \mu \mathrm{M}-2.5 \mu \mathrm{M}$ where as the untreated cells comprised the CCL-119 cells in the media was used as negative control. After incubation, the cells were treated with extract and incubated for 72 hours. Then, $20 \mu \mathrm{l}$ of MTT was added to each well and incubated for 4 hours. $150 \mu$ of cell suspension was discarded and then replaced with $150 \mu \mathrm{l}$ of DMSO to dissolve the formazan crystal and incubated for 15 minutes. The plate was vortexed using autovortex for five minutes prior to measurement at $570 \mathrm{~nm}$ with an ELISA microplate reader. Cell viability was calculated using the following formula:

$$
\% \text { cell viability }=\frac{\text { Mean OD Sample }}{\text { Mean OD control negative }} \times 100
$$

\section{Determination of Mode of Cell Death}

Flow cytometry Annexin V-FITC/PI assay was used to determine the mode of cell death induced by the acetone extract from C. odontophyllum twigs. A total volume of $2.25 \mathrm{ml}$ of CCL119 suspension cells at 105 cells/ml were seeded in each well of the 6-well microtitre plate and incubated for 48 hours. The cells were treated with $\mathrm{IC}_{25}$ and $\mathrm{IC}_{50}$ acetone extract twiqs and incubated for 72 hours. Next, the cells were centrifuged at 2500 rpm for 5 minutes at $4{ }^{\circ} \mathrm{C}$. The supernatant was removed and cold PBS was added and centrifuged. This process was repeated for 3 times. A total of $150 \mu \mathrm{l}$ of Annexin binding buffer (1x) followed by $5 \mu \mathrm{l}$ of Annexin V-FITC (eBioscience, Austria) was added into the tube and left for 15 minutes in ice. Next, $10 \mu \mathrm{l}$ of propidium iodide (eBioscience, Austria) at $20 \mu \mathrm{g} / \mathrm{ml}$ was added and incubated in ice condition for another two minutes and finally, $350 \mu \mathrm{l}$ of annexin binding buffer(1x) (eBioscience, Austria) was added into each tube. The solution in the centrifuge tube was then transfer redinto a Falcon tube to be analysed by flow cytometry(BD FASCCanto II) with Cell Quest software (BDSciences, America).

\section{Alkaline Comet Assay}

Alkaline comet assay was used to assess genotoxic damage of CCL-119 by acetone extract from C. odontophyllum twigs at $\mathrm{IC}_{25}$ and $\mathrm{IC}_{50}$ values. A total of $3 \mathrm{ml}$ of CCL-119 suspension cell with concentration at $1 \times 10^{5} \mathrm{cells} / \mathrm{ml}$ was seeded in each well of 6 -well microtitre plate and incubated for 48 hours. The cells were then treated with acetone extract twigs and left to incubate for 30 minutes before all the media in the well was collected into a centrifuge tube. The wells were washed twice with PBS solution. The solutions were centrifuged at $2500 \mathrm{rpm}$ for 5 minutes at $4^{\circ} \mathrm{C}$. The supernatant in each centrifuge tubes were discarded and this process was repeated. The Low Melting Agar (LMA) and Normal Melting Agar (NMA) were preheated until the agar melted. When the NMA reached a temperature of $37^{\circ} \mathrm{C}$, a total of $100 \mu \mathrm{L}$ of NMA was pipetted onto a frosted slide and a coverslip was placed on top of the slide and was then taken out slowly after the agar hardened. Next, about $80 \mu \mathrm{L}$ of LMA was added into each sample tube on top of the prepared NMA slide and a coverslip was placed slowly onto the two layers of gel and kept on ice surface. The coverslip was again taken out slowly and was placed in a coplin jar filled with the lysis solution and cooled at $4^{\circ} \mathrm{C}$ for about 24 hours before the slides were taken out and placed on the electrophoresis tank. Electrophoresis buffer was added into the tank to immerse the slide for 20 minutes to allow the DNA strands to unwind. The electrophoresis process was carried out for 20 minutes at $25 \mathrm{~V}$ and $300 \mathrm{~mA}$ after which the slides were rinsed with neutralizing buffer three times for every 5 minutes. The slides were then stained with $50 \mu \mathrm{l}$ of ethidium bromide at $20 \mu \mathrm{g} / \mathrm{ml}$. The slides were then analyzed using fluorescent microscope. The percentage of DNA in tail was determined by scoring the DNA using Comet Score software. This parameter reflects the degree of DNA damage in leukemic cells.

\section{Giemsa Staining}

This parameter was a qualitative method to observe the morphology of CCL-119 cells after treatment of acetone extract C. odontophyllum twigs.The CCL-119 cells were treated with $\mathrm{IC}_{25}$ and $\mathrm{IC}_{50}$ of $C$. odontophyllum acetone extract for 2 hours. Then, the treated cells were centrifuged at $1500 \mathrm{rpm}$ for 5 minutes. The supernatant was discarded and the pellet was suspended with $0.5 \mathrm{ml}$ of culture media. Then, few drops of cell suspension was dropped on the slide and a round thin smear was formed using pasteur pipette. After the smear dried, a few drops of methanol was added on the slide for 3 minutes in order to fix the cells followed by a few drops of Giemsa stains for another 5 minutes. Then, the slides were washed using running tap water and were left to dry. The slides were then covered with coverslip using DPX (distyrene, plasticiser, xylene) mounting medium and observed using light microscope. This procedure was repeated for dexamethasone. 


\section{Statistical Analysis}

All data were analysed by using SPSS Software Version 21. The data were expressed as the mean \pm S.E.M. from three different experiments. One way ANOVA was used to measure statistical differences between the mean in all experiments. The statistical difference was indicated with the value $\mathrm{p}<0.05$.

\section{Results}

\section{Evaluation of Cytotoxicity}

Figure 1 and Figure 2 showed percentage of cell viability against acetone extract from C. odontophyllum twigs and dexamethasone against CCL-119 respectively. Figure 1 showed the percentage cell viability decreased significantly from 0.25 $\mathrm{mg} / \mathrm{ml}$ to $2 \mathrm{mg} / \mathrm{ml}$ compared to negative control after 72 hours of treatment. The $\mathrm{IC}_{25}$ dan IC $\mathrm{I}_{50}$ of this extract were $0.37 \pm 0.02 \mathrm{mg} /$ $\mathrm{ml}$ and $0.93 \pm 0.09 \mathrm{mg} / \mathrm{ml}$ respectively. Figure 2 showed that the percentage of cell viability decreased significantly as compared to negative control after exposure of 72 hours of treatment with dexamethasone. The $\mathrm{IC}_{25}$ and $\mathrm{IC}_{50}$ of dexamethasone were $0.15 \pm$ $0.01 \mu \mathrm{M}$ and $0.34 \pm 0.01 \mu \mathrm{M}$.

\section{Determination of Mode of Cell Death}

Based on figure 3, control negative showed the highest percentage of viable cells as compared to other groups which was $81 \pm 3.67 \%$. The percentage of apoptosis increased significantly in $\mathrm{IC}_{50}$ of acetone extract twiqs as compared to negative control which was $76.17 \pm 2.38 \%$. The percentage of viable cells at $\mathrm{IC}_{25}(61.5 \pm 3.16 \%)$ of acetone extract twiqs was significantly different as compared to negative control. Besides, there was a significant difference $(\mathrm{p}<0.05)$ of percentage of viable cells when treated at $\mathrm{IC}_{50}$ and $\mathrm{IC}_{25}$ of dexamethasone, $43.8 \pm 4.5 \%$ and 38.53 $\pm 6.09 \%$ respectively when in comparison with the percentage of viable cells of negative control ( $81 \pm 3.67 \%$ ).

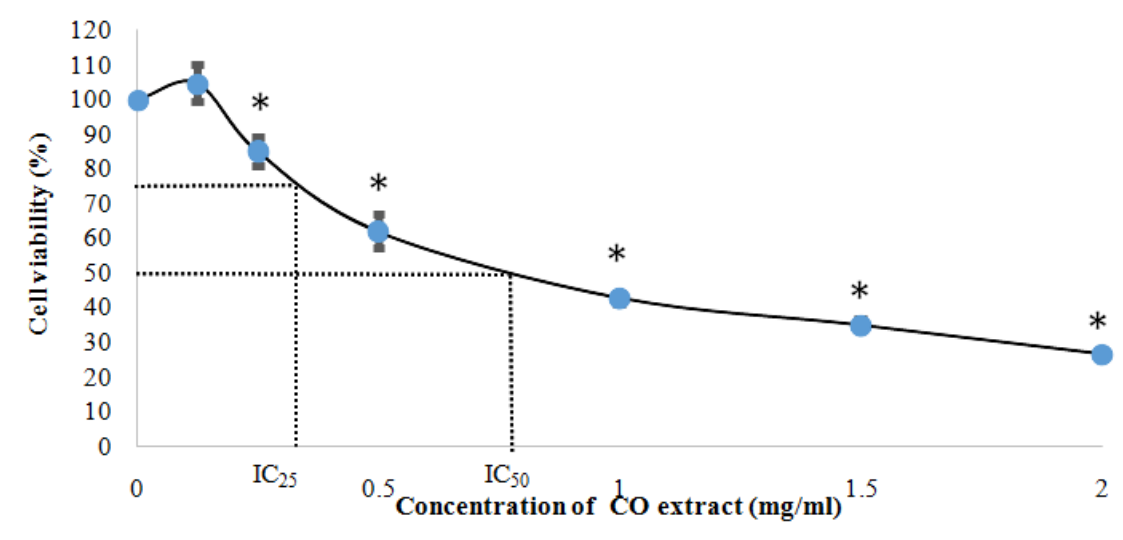

Figure 1: The average percentage of cell viability against concentration of C.odontophyllum ranging from $0.125 \mathrm{mg} / \mathrm{ml} \mathrm{to} 2 \mathrm{mg} / \mathrm{ml}$ after 72 hours of treatment. Values are expressed as mean \pm S.E.M. $(n=3)$.

* indicates significant difference as compared to the negative control.

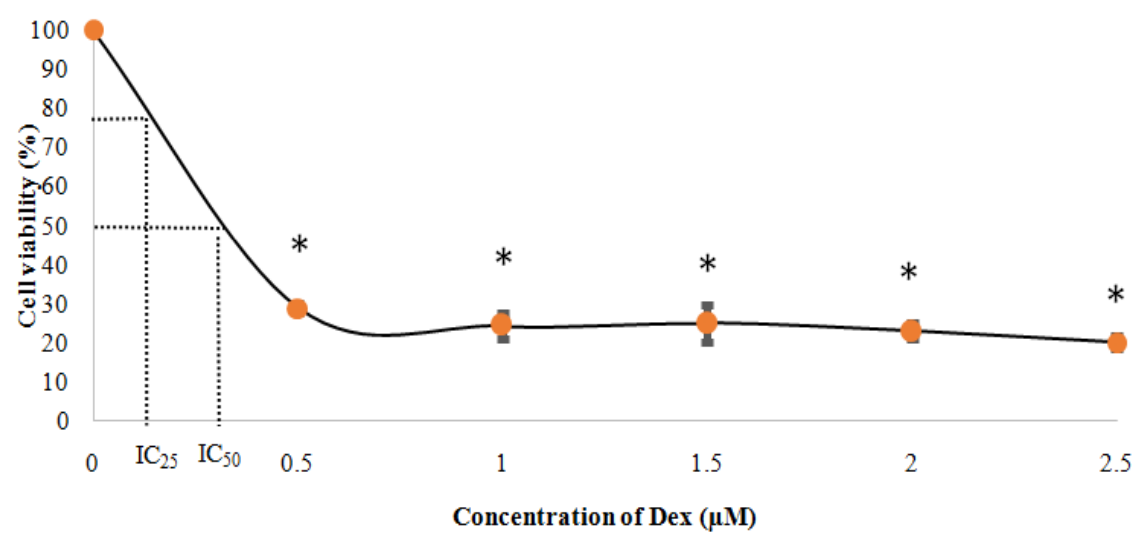

Figure 2: The average percentage of cell viability against concentration of dexamethasone ranging from $0.5 \mu \mathrm{M}$ to $2.5 \mu \mathrm{M}$ after 72 hours of treatment. Values are expressed as mean \pm S.E.M. $(\mathrm{n}=3)$.

* indicates significant difference as compared to the negative control. 


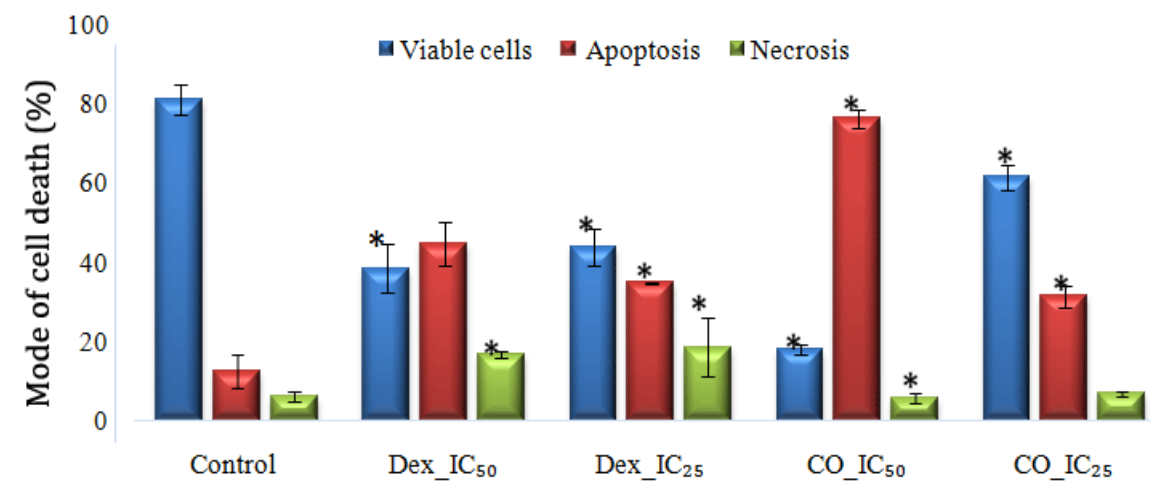

Figure 3: Barchart of comparison between the percentage of viable cells, apoptotic cells and necrotic cells against $\mathrm{IC}_{50}$ and $\mathrm{IC}_{25}$ of extract of $\mathrm{CO}_{\text {and }}$ DEX after 72 hours of treatment. Values are expressed as mean \pm S.E.M. where $\mathrm{n}=3$.

* indicates significant difference as compared to the negative control.

\section{Alkaline Comet Assay}

Figure 4 presented the percentage of DNA in tail of HCT 116 cells after treatment with acetone extract twiqs of $C$. odontophyllum at its $\mathrm{IC}_{25}$ and $\mathrm{IC}_{50}$ values. The percentage of tail at $\mathrm{IC}_{25}(13.51 \pm 2.73 \%)$ and $\mathrm{IC}_{50}(15.46 \pm 2.02 \%)$ of acetone extract increased significantly as compared to control negative $(0.48 \pm 0.29)$. The percentage of tail at $\mathrm{IC}_{25}(14.20 \pm 2.81)$ and $\mathrm{IC}_{50}$ $(32.11 \pm 4.73)$ of dexamethasone showed a significant increased as compared to control negative. Figure 5 showed the DNA migration in treated CCL-119 cells but no DNA migration was seen in untreated CCL-119 cell (negative control).

\section{Giemsa Staining}

Figure 6 showed the photo of CCL-119 cell stained with Giemsa stain under light microscope for 2 hours. Photo A showed the negative control which is the untreated cells. The cells were intact and showed membrane bound cytoplasm. Photo B showed the CCL-119 cells treated with $\mathrm{IC}_{50}$ of dexamethasone. The cells have undergo membrane blebbing and shrinkage of cells as compared to negative control. Photo C showed CCL-119 cells treated with $\mathrm{IC}_{50}$ of acetone extract from $C$. odontophyllum twig. The cells showed membrane blebbing properties and cell shrinkage.

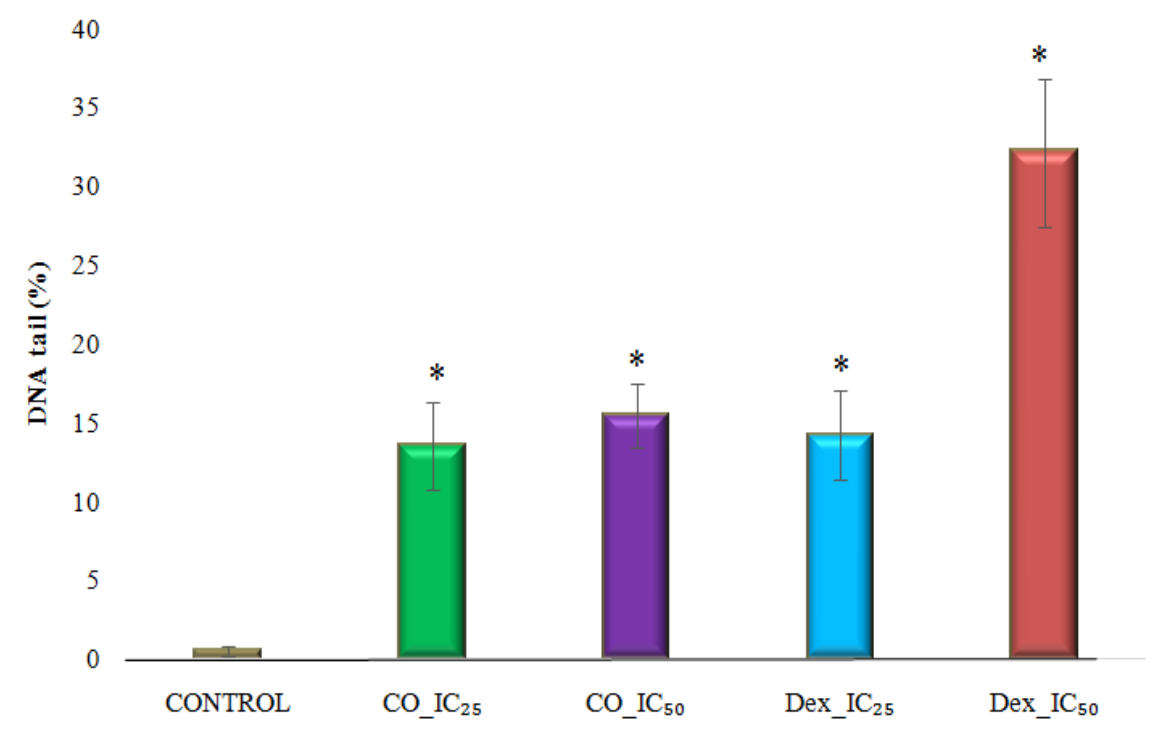

Figure 4: Bar chart of percentage of DNA tail against treatment of IC50 and IC25 of CO extract and DEX for 30 minutes. Values are expressed as mean \pm S.E.M. where $n=3$.

* indicates significant difference as compared to the negative control. 


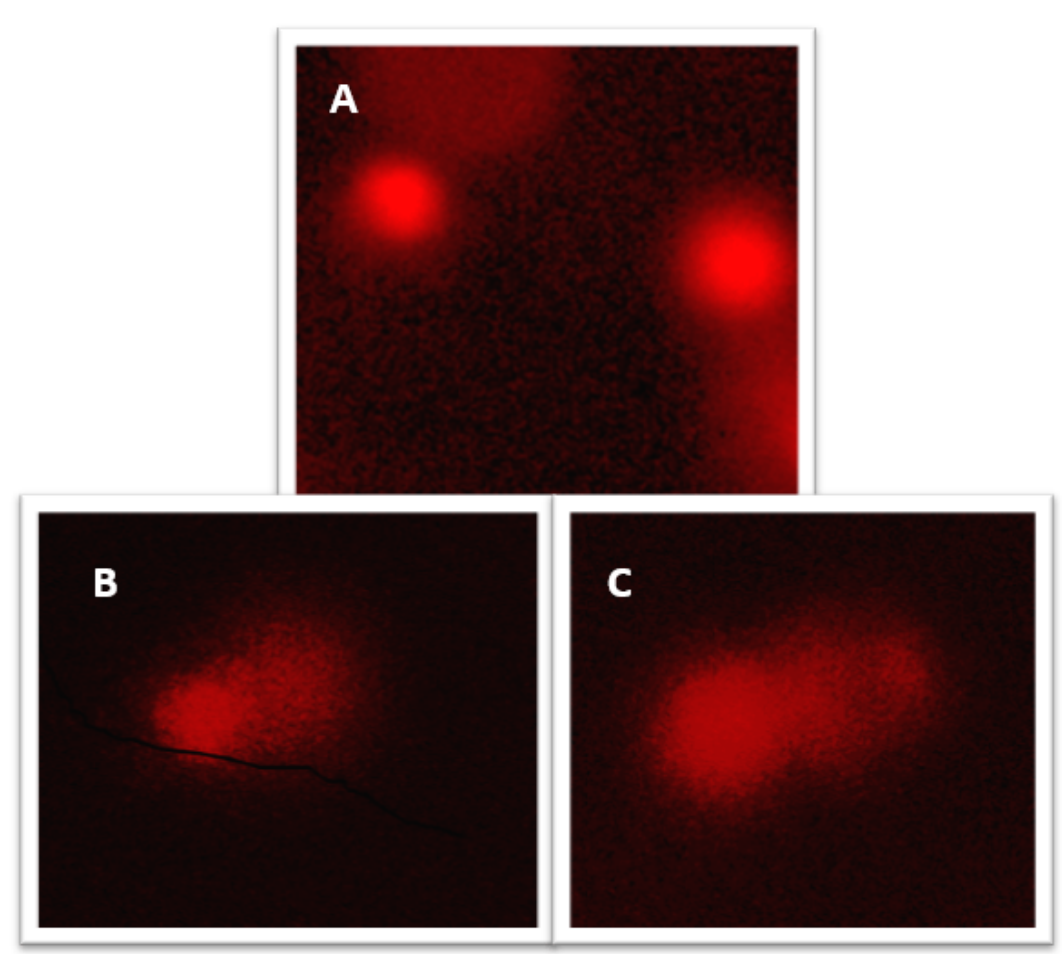

Figure 5: Photo of CCL-119 cells stained with ethidium bromide under fluorescent microscope at $30 \mathrm{~min}$. (A) Negative control: untreated cell (B) DNA migration induced by DEX at IC ${ }_{50}$ (C) DNA migration of CCL-119 cell induced by acetone extract CO IC ${ }_{50}$.

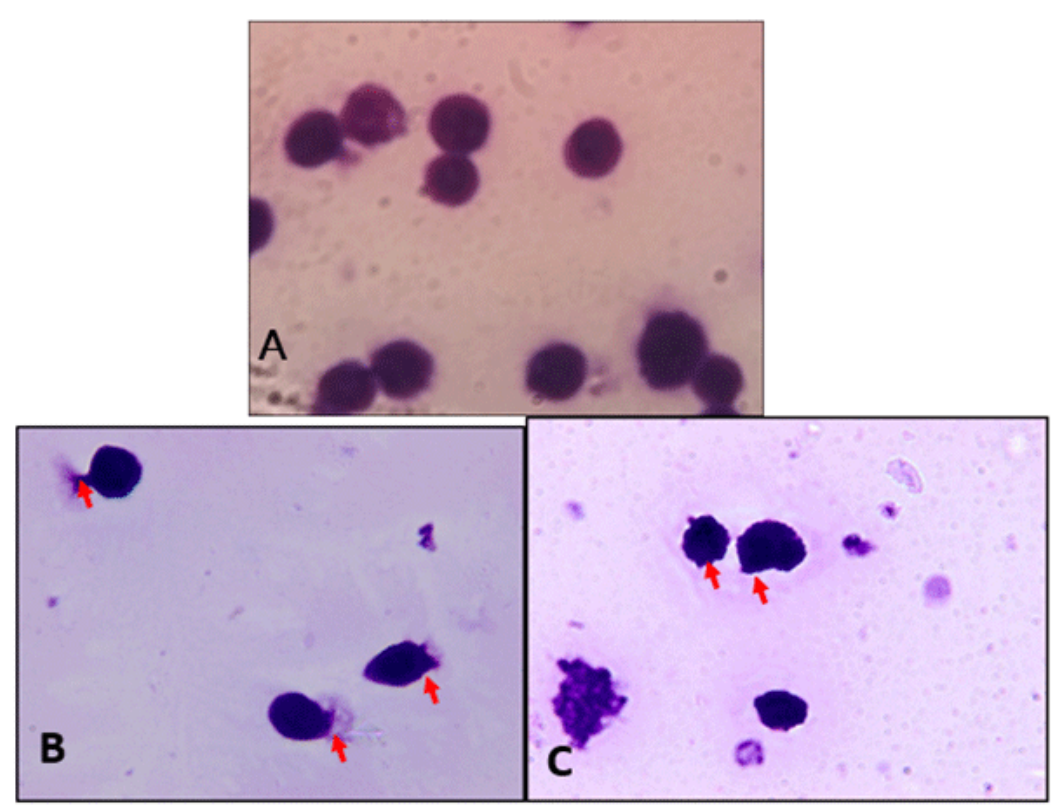

Figure 6: Photo A showed the negative control which is the untreated cells. The cells were intact and showed membrane bound cytoplasm. Photo $\mathbf{B}$ showed the CCL-119 cells treated with IC ${ }_{50}$ of DEX. The cells have undergo membrane blebbing and shrinkage of cells as compared to negative control. Photo $\mathbf{C}$ showed CCL-119 cells treated with IC ${ }_{50}$ of acetone extract. The cells showed membrane blebbing properties and cell shrinkage. 


\section{Discussion}

Leukemia is one of the hematologic malignancies in which the malignant white cells accumulate in bone marrow and peripheral blood [13]. Acute Lymphoblastic Leukemia (ALL) is one of the type of leukemia which is common in children and it represents $25 \%$ of pediatric cancer [14]. There are many synthetic drugs given clinically during chemotherapy to treat leukemic patients to induce cell death [15]. Dexamethasone is one of the glucocorticoid which is used as a chemotherapeutic drug to treat ALL patients. Dexamethasone acts as anti inflammatory drug and able induce apoptosis in cancer cells. However, this drug exhibits many side effects such as emotional changes, anxiety, aggressiveness and sleeping disorder $[16,17]$.

Plant-based anticancer agents are being explored more to be developed into a potential anticancer agent with minimal or no side effects. Canarium odontophyllum (CO) which is also known as dabai has been used as it exerts cytotoxicity towards cancer cell line [6]. In this study, acetone extract C.odontophyllum twigs was used to determine the toxicological effect on acute lymphoblastic leukemia CCL-119 cells.

Based on the MTT assay, acetone extract CO twigs and dexamethasone able to exhibit cytotoxicity towards the CCL-119 cells after exposure of 72 hours. This cytotoxicity of cells are due to the phytochemicals such as polyphenol, tannin, terpenoid and flavonoid which present in the acetone extract CO twigs [18]. In addition, terpenoid has the cytotoxic properties in cancer cells [19]. Other than that, the flavonoid exerts anti-tumour and cytotoxicity properties in cancer cells $[20,21]$.

However, the value of $\mathrm{IC}_{50}$ of $\mathrm{CO}$ is higher than the $\mathrm{IC}_{50}$ of dexamethasone. This is because dexamethasone is a drug that is given clinically to patients in order to kill cancer cells even at low dose [22]. Thus, this shows that high concentration of acetone extract are needed in order to be cytotoxic towards the CCL-119 cells. Based on previous study, the $\mathrm{IC}_{50}$ acetone extract CO twigs is $25 \mu \mathrm{g} / \mathrm{ml}$ towards the colorectal cancer HCT-116 cell line [6]. This suggest that different type of cancer cell lines exhibit different IC $_{50}$ values. Leukemia is a hematological cancer whereas the colorectal cancer is tumor growth on the epithelium layer of colorectal [23,24]. In addition, extract Amoora chittagonga exerts cytotoxicity with two different $\mathrm{IC}_{50}$ values on two different cell line which include breast cancer MCF-7 cell line and pancreatic cancer cell line HTB126 [25].

The mode of cell death was determined by using Annexin V-FITC/PI staining assay towards the CCL-119 cells after treat with acetone extract CO twigs. Dexamethasone acts as positive control in this study. The results showed that both acetone extract $\mathrm{CO}$ and dexamethasone induce apoptosis on CCL-119 after 72 hours of treatment. Apoptosis is one of mode of death which is favourable in anti cancer research. This is due to its properties that does not disturb the neighboring cells and the apoptotic bodies will be destroyed by phagocytosis without trigger inflammation of cells $[11,26]$.

Based on result obtained from MTT assay and Annexin
V-FITC/PI staining assay, the percentage of cell viability varies in both parameters. This is because both parameters measure the different endpoint assessment [27]. MTT assay evaluation is based on the involvement of active mitochondria in living cell that is able to produce succinate dehydrogenase. This enzyme can change the yellow MTT salt into purple colour formazan. On the other hand, Annexin V-FITC/PI staining assay based on the detection of externalization of phosphotidylserine at outer membrane of apoptotic cells [28,29]. However, the MTT assay measures only the viable cells whereas the Annexin V-FITC/PI staining determines the percentage of viable cells and also known percentage of mode of cell death [5]. Thus, this differences gives the variation of results in two different parameters.

Besides, the mode of cell death of HL-60 leukemic cell after treatment with ethyl acetate extract from the twigs of Cudrania tricuspidata was also via apoptosis [30]. In addition, studies found that acetone extract from the twigs of CO contain many phytochemicals which include polyphenol can induce apoptosis in cancer cells. The mode of cell death of colorectal cancer cell line HCT-116 treated with acetone extract CO twigs was via apoptosis [6,18,31].

The cytotoxicity effect on CCL-119 cells after treatment of acetone extract twigs $\mathrm{CO}$ might be due to DNA damage. In addition, genotoxic effect is one of early mechanism of cell death via apoptosis. This study showed that CCL-119 cells have undergone DNA damage after 30 minutes exposure of treatment of acetone extract CO twigs and also control positive as dexamethasone. In addition, result showed the percentage of DNA tail of CCL-119 increases significantly as compared to control negative. Acetone extract CO twigs were able to damage the DNA of HCT-116 colorectal cancer cells within 30 minutes [6].

Other than that, membrane blebbing and cell shrinkage are the properties of apoptotic cells. Cell morphology observation was done in order to observe the blebbing of cells after 2 hours of exposure of acetone extract $\mathrm{CO}$ twigs and dexamethasone using Giemsa stain. The ovarian cancer CAOV-3 also showed membrane blebbing properties after treat with roots of Enicosanthellum pulchrum [32]. Furthermore, the phytochemical present in the acetone extract such as phenol can induce nuclear fragmentation in cells [33]. Thus, 2 hours of treatment with acetone extract from the twigs of Canarium odontophyllum were able to show membrane blebbing and cell shrinkage towards the CCL-119 cells.

\section{Conclusion}

Acetone extract from the twigs of Canarium odontophyllum was capable of causing cytotoxic effect on CCL-119 cells. The mode of cell death was via apoptosis by inducing DNA damage in the cells. Thus, this extract has the potential to developed as anticancer agent. However, as this is a novel study of CO extract on hematological malignancy, further studies need to be done on other different types of ALL cell lines. In conclusion, CO extract can offer as an alternative phytochemotherapeutic agent in the treatment against acute leukemia in pediatric patients in addition to improving their life expectancy as well as quality of life. 


\section{Acknowledgement}

This project was funded by Universiti Kebangsaan Malaysia under the Research University Grant Code Grant GUP-2016-036.

\section{References}

1. Hoffbrand A V, Moss P A H. Essential Hematology $7^{\text {th }}$ edition. Wiley Blackwell. 2016.

2. Yeoh A E J, Tan D, Li C, Hori H, Tse E, Pui C. Management of adult and paediatric acute lymphoblastic leukaemia in Asia: resource-stratified guidelines from the Asian Oncology Summit 2013. Lancet Oncol. 2013;14(12):e508-e523. Doi:10.1016/S1470-2045(13)70452-2

3. Cancer Facts \& Figures. American Cancer Society. 2016.

4. Unnati S, Ripal S, Sanjeev A, Niyati A. Novel anticancer agents from plant sources. Chin J Nat Med. 2013;11(1):16-23. Doi: org/10.1016/S18755364(13)60002-3

5. Basri D F, Alamin Z A Z, Chan K M. Assessment of cytotoxicity and genotoxicity of twigs extracts from Canarium odontophyllum Miq (dabai) against HCT 116 human colorectal cancer cell line. BMC Complement Altern Med. 2016;16(36):1-12. Doi: 10.1186/s12906016-1015-2

6. Basri D F, Mohd M A A, Meng C K, Latif E S, Huyop F Z. Leaves Extract from Canarium odontophyllum Miq. (dabai) Exhibits Cytotoxic Activity against Human Colorectal Cancer Cell HCT 116. Natural Products Chemistry \& Research. 2015;3(2). Doi: 10.4172/2329-6836.1000166

7. Shakirin F H, Prasad K N, Ismail A, Yuon L C, Azlan A. Antioxidant capacity of underutilized Malaysian Canarium odontophyllum (dabai) Miq fruit. J Food Compost Anal. 2010;23(8):777-78. Doi: org/10.1016/j. jfca.2010.04.008

8. Huang M, Lu J J, Huang M Q, Bao J L, Chen X P, Wang Y T. Terpenoids: natural products for cancer therapy. Expert Opin Investig Drugs. 2012;21(12):1801-1818. Doi:10.1517/13543784.2012.727395

9. Liu Y, Whelan R J, Pattnaik B R, Ludwig K, Subudhi E, Rowland H, et al. Terpenoids from Zingiber officinale (Ginger) Induce Apoptosis in Endometrial Cancer Cells through the Activation of p53. PLOS One. 2012;7(12):e53178. Doi: 10.1371/journal.pone.0053178

10.Lia D, Dua Z, Lia C, Liuc Y, Goodind S, Huanga H, et al. Potent inhibitory effect of terpenoids from on growth of PC-3 prostate cancer cells in vitro and in vivo is associated with suppression of NF- $\kappa \mathrm{B}$ and STAT3 signalling. J Funct Foods. 2015;15:274-283. Doi: org/10.1016/j. jff.2015.03.035

11.Huerta S, Goulet E J, Livingston E H. Colon cancer and apoptosis. Am J Surg. 2006;191(4):517-526. Doi: 10.1016/j.amjsurg.2005.11.009

12.Greenwell M, Rahman P K S M. Medicinal Plants: Their Use in Anticancer Treatment. Int J Pharm Sci Res. 2015; 6(10):4103-4112. Doi: 10.13040/IJPSR.0975-8232.6(10).4103-12

13.Taverna S, Corrado C. Natural Compounds: Molecular Weapons against Leukemia's. J Leuk. 2017;5(1):1-7. Doi: 10.4172/2329-6917.1000226

14.Sverre Heim, Felix Mitelman. Cancer Cytogenetics: Chromosomal and Molecular Genetic Aberrations of Tumor Cells. Fourth Edition. United Kingdom: John Wiley \& Sons. 2015. Doi: 10.1002/9781118795569

15.Jayachandran D, Rundell A E, Hannemann R E, Vik T A, Ramkrishna D. Optimal Chemotherapy for Leukemia: A Model-Based Strategy for Individualized Treatment. PLoS One. 2014;9(10):1-18. Doi:10.1371/ journal.pone.0109623
16.Hinds P S, Hockenberry M J, Gattuso J S, Srivastava D K, Tong X, Jones H, et al. Dexamethasone alters sleep and fatigue in pediatric patients with acute lymphoblastic leukemia. Cancer. 2007;110(10):2321-2330. Doi: 10.1002/cncr.23039

17.Vries A C, Grieken N C, Looman C W, Casparie M K, Vries E, Meijer G A, et al. Gastric cancer risk in patients with premalignant gastric lesions: a nationwide cohort study in the Netherlands. Gastroenterology. 2008;134(4):945-952. Doi: 10.1053/j.gastro.2008.01.071

18.Basri D F, Heng K Y, Meng C K, Ghazali A R. Screening of antioxidant phytoextracts of Canarium odontophyllum (Miq.) leaves in vitro. Journal Of Pharmacy. 2014;4(12)

19.Hadi S M, Asad S F, Singh S, Ahmad A. Putative mechanism for anticancer and apoptosis-inducing properties of plant-derived polyphenolic compounds. IUBMB Life. 2000;50(3):167-171. Doi: $10.1080 / 152165400300001471$

20.Kanadaswami C, Lee L T, Lee P P H, Hwang J J, Ke F C, Huang Y T, et al. The antitumor activities of flavonoids. In vivo. 2005;19(5):895-909.

21.Yadegarynia S, Pham A, Ng A, Nguyen D, Lialiutska T, Bortolazzo A, et al. Profiling flavonoid cytotoxicity in human breast cancer cell lines: determination of structure-function relationships. Nat Prod Commun. 2012;7(10):1295-304.

22.Abdoul-Azize S, Buquet C, Vannier J, Dubus I. Pyr3, a TRPC3 channel blocker, potentiates dexamethasone sensitivity and apoptosis in acute lymphoblastic leukemia cells by disturbing Ca2p signaling, mitochondrial membrane potential changes and reactive oxygen species production. Eur J Pharmacol. 2016;784:90-98. doi: 10.1016/j. ejphar.2016.05.014

23.Porth CM. Essentials of pathophysiology: concepts of altered health states 3rd Edition. Lippincott Williams \& Wilkins, 2011.

24.Underwood JCE, Cross SS. General and Systemic Pathology. Churchill Livingstone: Elsevier; 2009:395.

25.Chan LL, George S, Ahmad I, Saujanya L, Gosangari, Abbasi A, et al. Cytotoxicity Effects of Amoora rohituka and chittagonga on Breast and Pancreatic Cancer Cells. J Evid Based Complementary Altern Med. 2011.

26.Badmus JA, Ekpo OE, Hussein AA, Meyer M, Hiss DC. Antiproliferative and Apoptosis Induction Potential of the Methanolic Leaf Extract of Holarrhena floribunda (G. Don). J Evid Based Complementary Altern Med. 2015

27.Chan KM, Rajab NF, Siegel D, Din LA, Ross D, Inayat-Hussain SH. Goniothalamin Induces Coronary Artery Smooth Muscle Cells Apoptosis: The p53-Dependent Caspase-2 Activation Pathway. Toxicol Sci. 2010;116(2):533-548. DOI: 10.1093/toxsci/kfq151

28.Demchenko AP. Beyond annexin V: fluorescence response of cellular membranes to apoptosis. Cytotechnology. 2013;65:157-172. DOI: 10.1007/s10616-012-9481-y

29.Mosmann T. Rapid Colorimetric Assay for Cellular Growth and Survival: Application to Proliferation and Cytotoxicity Assays. J Immunol Methods. 1983;65(1-2):55-63.

30.Seo W, Pae H, Oh G, Chai K, Yun Y, Chung H, et al. Ethyl Acetate Extract of the Twigs of Cudrania Tricuspidata Induces Apoptosis in Human Leukemia HL-60 Cells. ‘Am J Chin Med. 2001;29(2):313-320.

31.Carocho M, Ferreira ICFR. The Role of Phenolic Compounds in the Fight against Cancer - A Review. Anticancer Agents Med Chem. 2013;13(8):1236-1258 
32.Nordin N, Fadaeinasab M, Mohan S, Hashim NM, Othman R, Karimian H, et al. Pulchrin A, a New Natural Coumarin Derivative of Enicosanthellum pulchrum, Induces Apoptosis in Ovarian Cancer Cells via Intrinsic Pathway. PLoS One. 2016;11(5):e0154023. doi: 10.1371/ journal.pone.0154023

33.Taraphdar AK, Roy M, Bhattacharya RK. Natural products as inducers of apoptosis: Implication for cancer therapy and prevention. Curr Sci. 2001;80(11):1387-1396. 